\title{
A VISIT TO THREE LEPER SETTLEMENTS
}

J. How ard Cook.

At the end of May last year I returned from a five months' tour, through Uganda and the Sudan, deeply impressed by the value of co-operation in the prevention and treatment of leprosy.

There are many partners in this great co-operative ventureThe British Government, the Native Administration, B.E.L.R.A., Toc $\mathrm{H}$, the Mission to Lepers, and Missionary Societies like the C.M.S. and R.C. Missions-all working, or helping the work, in the areas I visited.

Compulsion is no longer found necessary in the treatment of leprosy, attraction has taken its place. Hence, lepers come at an earlier, and more amenable, stage of the disease. This gives new hope to the once hopeless patient, and attracts others. Occupa- 
tional therapy gives an added interest to life and reduces cost of maintenance. Education fits the leper for a share in the administration of his colony and in the treatment of fellow-lepers.

Three places that I visited specially show the value of cooperation, and the generous help that has been given by B.E.L.R.A. in many ways.

\section{C.M.S. Leper Settlement, BWama lsland (L. Bunyonyi), UGANDA}

This island was visited by Dr. Muir on May I7th and I8th, I938, my visit was nine months later, March 3rd, I939. Dr. Muir's report,* which I had with me, was a great help, for I was able to go through it, point by point, with the staff, and see how far his recommendations had been carried out.

The West end of the island, including the two promontories known as Jericho and Nazareth, have been set apart for the isolation of infective cases of leprosy. Twelve advanced nodular cases, found by Dr. Muir in the school at Bethany (East end of the island), were on his advice transferred to the quarantine area. Four more cases, which he suspected, but regarded as " nonproven," were later found to be bacteriologically positive, and were quarantined. A general survey of every case on the island is now made at least once a year. At the time of my visit there were over 90 cases isolated as a result of slides having been taken and found positive by nasal or skin tests.

Children hitherto living with infectious parents have, since Dr. Muir's visit, been housed at night with non-infectious families, and during the greater part of the day they are also parted from their parents (e.g., during school hours, or sports). Contact only arises through the children at present having to help their parents cultivate and at meal times.

Seven recommendations for treatment made by Dr. Muir have been carried out with benefit. The diet of the patients has been improved. Two fishermen are employed exclusively for the island. Eggs are obtained for the Crèche children. Fresh vegetables and fruits are increasingly grown.

Since Dr. Muir's visit, 42 cases that became " symptom-andsign-free " had been discharged by the time of my visit, making room for fresh acute cases.

I spent a considerable time at the Jericho end of the island, where I found 93 cases of leprosy quarantined. I am satisfied that no compulsion had been used to get 90 of these to go to the island for treatment. Three wished to leave, two because they were discouraged at not making more progress and "wanted to die at 
home." The third, I think, had a legitimate grievance. He had left his crops in the ground with no one to look after them, and when his chief advised him to go to Bwama for treatment, he took this to be a command. It isn't always easy to distinguish between advice and moral compulsion, if the advice comes from one's chief! On my suggestion he was allowed to go back to secure his crops.

Another example of B.E.L.R.A's help was the sending to this colony of an experienced Toc $\mathrm{H}$ man-Mr. Lambert-some months after I had left. I have no doubt that the help thus given will prove of inestimable value, both for agricultural development and the initiation of occupational therapy.

\section{Kumi and Ongino (F. Province, UGanda)}

The Ng'ora Leper Mission (C.M.S.) includes two settlements, one at Kumi-popularly known as the Children's Home-and the other at Ongino, about three miles distant. The latter is for acute adult cases. Formerly this branch of the work was at Kapiri, I5 miles from Kumi to the North, near Lake Salisbury.

The Kumi home was founded by Dr. C. A. Wiggins, and opened on February Ist, I930. It is a bit of a misnomer to call it by a name which suggests a single institution. It is really a settlement with many institutions-homes, schools, hospital, dispensary, sports grounds, etc. There is also a settlement for healthy children, separated trom the leper children by a broad road, and the careful vigilance of a very competent staff.

Dr. Wiggins started the work at Kapiri by the erection of a hospital for nodular cases. This was opened on November 8th, I930. The work was transferred to Ongino in 1935.

Both settlements owe a great deal to the generous help of Government, Mission to Lepers, and B.E.L.R.A.; and to Dr. Muir's helpful visit, May 3Ist-June $4^{\text {th, }}$ I938.*

Since this visit, and the high commendation that Dr. Muir was able to give to the work at Kumi and Ongino, I found the staff cheered and encouraged, and fired with increased zeal to try out new methods, and implement all the helpful advice he had given.

Government, which has always taken a keen interest in the work, had prior to my visit made increased grants, and the Governor had visited both settlements, shortly before my arriva] in Uganda.

At Ongino the social side of the settlement has not been overlooked. A shop is provided at which lepers can for a small outlay purchase books and other commodities. Healthy lepers are encouraged to cultivate small garden plots, thus securing food 
for the colony, and healthy exercise for the able bodied lepers. There are 400 lepers in the settlement.

At Kumi, shortly before my visit the staff had been strengthened by the transfer of a trained C.M.S. Nursing Sister, Miss A. F. Kent, to join the Superintendent, Miss Laing.

Nearly all the building in the Kumi settlement is done by non-infectious leper boys from the upper classes in the school. There is a model farm of cows, pigs, goats, sheep, ducks and poultry, also in charge of leper lads. Orchards of fruit trees provide a rich variety of vitamines, and a fringe of cassia trees surrounds the site where untainted children are reared.

The water problem has been solved along the lines suggested by Dr. Muir. The intermittent supply of rain water from rooftanks is supplemented in the dry season by the sinking of a new well, and the importation of a pump, which I found installed, and in use.

I was struck by the up-to-date methods of record keeping in the office of the Kumi settlement. This is based on Dr. James Maxwell's work on leprosy (Shanghai, 1937) the records being plotted out as graphs on a chart.

Perhaps the most spectacular thing I saw was the daily massage drill with hydnocarpus oil, and the charming games and dances performed by happy little groups of children.

$$
\text { III. *Lui (C.M.S.) S. Sudan. }
$$

At the time of my visit, April 4th, 1939, there were 75 lepers in the colony, the majority being "burnt-out" cases-sadly deformed and helpless; but, from a leprosy point of view, noninfective and to a large extent free from the disease. Only 20 were of the nodular type.

There is a leper school with leper teachers, supervised by Mrs. Fraser, who has lived nineteen years among the Moru tribe at Lui. Occupation therapy is encouraged. The able-bodied lepers cultivate their food in half-acre plots. Football and sports are encouraged.

Plans have been initiated for a P.T.S. (Propaganda-TreatmentSurvey) investigation of the needs of the district. The C.M.S. are sending a doctor to work with Dr. Casson, and B.E.L.R.A. has sent one of its Toc $\mathrm{H}$ experts to help in developing this research, and initiating plans for treatment. Government is prepared to co-operate and make substantial grants, though possibly the war may interfere with this. A C.M.S. house is ready for the new workers and the local Mission authorities thoroughly approved, and Dr. Casson is very keen on the whole scheme.

* Leprosy Review, Vol, X, No. I, Jan. 1939, pp.rg, 20, 3I, 4I. 